\title{
Effectiveness of Forestry Police in Preventing Illegal Logging Activity in North Halmahera Regency
}

\author{
Faisal \\ Faculty of Law, Khairun Ternate University \\ Yusuf Abdurahman Street, Gambe, Southern Ternate City, North Maluku, Indonesia \\ Phone:+62-8219833839, Email:faisaldjabid@gmail.com
}

DOI: $10.31957 / p l j . v 3 i 2.785$

\begin{abstract}
Illegal logging activity possess the greatest threat resulting in forest destruction due to illegal use of timber forest products in various forest areas in Indonesia, including in North Halmahera Regency. Through Law No. 41 of 1999 concerning forestry, forestry police was formed with special authority covering preventive measures, administrative and repressive operation to be able to maintain the implementation of optimal forest protection. Research method used was empirical legal research. The results indicated that illegal logging activities continued to occur in North Halmahera Regency due to the lack of awareness and desire of communities in the surrounding forest to prevent forest destruction activities, weak law enforcement against those who violate the Law in the forestry sector, and the lack of supporting facilities and infrastructure in carrying out forest protection activities and forest security. The various obstacles faced by the police in the scope of North Halmahera Regional Conservation Resort include the lack of legal socialization to the community, the absence of routine, sudden, and joint patrol activities in the forest area and the loss of coordination with agencies/institutions related to forest protection and security. This condition indicated that the Forestry Police (Polhut) in the scope of North Halmahera Regional Conservation Resort has not been optimal and effective in preventing illegal logging, so that it is necessary to strengthen the role of the Forestry Police in the future, and to make various per-emptive efforts, such as socializing the dangers of illegal logging and the importance of maintaining forest areas as a support for life in the future.
\end{abstract}

Keywords: Illegal Logging; Forestry Police

\section{INTRODUCTION}

Forest is a gift and trust from God Almighty for humanity, as a support for life and a source of human welfare on earth. In addition, forest is invaluable natural resources because it contains biodiversity as a source of germ plasma, timber and non-timber forest products, water management, flood and erosion prevention, and soil fertility, biological protection for the benefits of science, culture, recreation, tourism and so on. Therefore, its existence and ecosystem must be maintained 
continuously in order to remain sustainable. ${ }^{1}$

The foundation of thinking on the importance of maintaining a good and healthy environment is actually based on the nature of every human being lives in a clean and healthy environment. That is why awareness of a good environment and clean must be invested basically on every citizen because it is one of the basic needs. On the basis of that thought, the legislators also consider it necessary to formulate it in the Constitution ${ }^{2}$. Indonesia has approximately $133,419,000$ ha of forest. The forest area consists of protected forest of 30,097,000 ha, nature reserves and nature preservation of $27,453,000$ ha, limited production forest of 27,875,000 ha, permanent production forest of $30,180,000$ ha, and convertible production forest of 17,815.000 ha. ${ }^{3}$ As a country with

\footnotetext{
1 Murhaini Suriansyah. (2011). Hukum Kehutanan Penegakan Hukum Terhadap Kejahatan Di Bidang Kehutanan. Yogyakarta: Laksbag Grafika. p. 9.

${ }^{2}$ Hotlan Samosir. (2017). Responsibility of Local Government Against Sea Pollution, Plastic Waste In Sea Waters, Sorong City. Papua Law Journal. Vol. 2 Issue 1, November. p. 97

http://www.bps.go.id/tab_sub/view.php?kat= 3\&tabel=1\&daftar. accessed on April 23, 2018.
}

extensive forest, the government faces various problems. One of the most striking problems in the forestry sector is the widespread practice of illegal logging.

North Halmahera Regency has a forest area of 393,562.47 $\mathrm{Ha}$ consisting of Protection Forest (HL) of 77,785.55 Ha, Production Forest (HP) of $21,898.73 \mathrm{Ha}$, Limited Production Forest (HPT) of 69,740.40 Ha, Convertible Production Forest (HPK) of $131,779.32$ ha and nonforest estate (APL) of 92,356.47 ha.

In terms of preventing and limiting the destruction of forest, forest area and forest product caused by irresponsible human acts, maintaining and safeguarding the rights of the state, society and individuals over the forest, the efforts to protect forest need to be carried out. To guarantee the implementation of forest protection, in accordance with Article 5 Law of the Republic of Indonesia Number. 41 of 1999 concerning Forestry, certain forestry officials according to their work nature are granted special authority, in this case the Forestry Police. The authority of Forestry Police includes activities and police measures 
specifically in the area of preventive forestry, administrative measure and repressive operation.

Considering the vast area of forest in Halmahera Regency with a alarming level of vulnerability to perpetrators of criminal offenses against forests and forest products in the form of illegal logging, transportation of timber without legal documents, smuggling of timber/other forest products, and forest encroachment, it is necessary to carry out the protection and management of forest security, by strengthening the role of the Forestry Police, especially the role of preventive measures. Based on the existing problems, the author was interested to conduct a study entitled the effectiveness of forestry police in preventing illegal logging activity in North Halmahera regency. This study focused on the factors causing illegal logging activities in North Halmahera Regency and the obstacles faced by forestry police of North Halmahera Regional Conservation Resort in preventing illegal logging activities.

\section{METHOD}

The type of research was
empirical juridical research, by

conducting an examination of the various effectiveness of the role of the forestry police as an institution granted special authority in monitoring, preventing and prosecuting acts of illegal logging in North Halmahera and its relation to individual or community behavior. ${ }^{4}$ In addition, this study was combined with the type of normative juridical research to examine the laws and regulations relating to the legislation in the area of forestry, especially in preventing and combating illegal logging.

Data sources in this study included primary data derived from communities living in the vicinity of the forest, and perpetrators of illegal logging and Forestry Police with special authority to carry out police duties specifically in the forestry sector. Whereas secondary data was obtained through primary legal sources, namely laws and regulations, and local government policies in preventing and combating illegal logging in North Halmahera, the source of secondary legal material was derived from scientific works and

4 Peter Mahmud Marzuki. (2008). Penelitian Hukum. Jakarta: Kencana Pranada Media Group, p. 87 
the sources of tertiary legal material were derived from legal dictionary and legal encyclopedia.

All data were inventoried and grouped for further qualitative descriptive analysis to explain the effectiveness of the role of the forestry police in preventing illegal logging activity in North Halmahera.

\section{DISCUSSION}

Factors Affecting the Practice of Illegal Logging In North Halmahera Regency

Determination of North Halmahera Forest Area is based on Minister of Forestry Decree Number: SK.302/Menhut-II/2013 issued for forest areas in North Maluku Province, managed by each Regency/City based on Regency administrative boundaries. Based on data from the Planning and Development of Department of Forestry in North Halmahera Regency in 2017, total forest area of North Halmahera Regency according to Minister of Forestry Decree Number 302 of 2013 is $337,402.29 \mathrm{Ha}$ consisting of $\mathrm{HL}$ of $77,374.61 \mathrm{Ha}$, HPT of $71,719.96 \mathrm{Ha}, \mathrm{HP}$ of 19,925.74 Ha, HPK of 75,852.20 Ha, and APL of 92,529.78 $\mathrm{Ha}$. The small forest area is prone to illegal logging activities that threaten the sustainability of forests in North Halmahera Regency.

This is inseparable from the people activities around the forest area. Based on the results of this study, the factors causing people to practice illegal logging includes:

\section{Lack of Public Awareness in Maintaining and Protecting the Forest}

Public awareness in maintaining and protecting the forest can be seen from the community behavior around the forest area that seemed not to care about the consequences of illegal logging activities. Most people living near or in the forest area did not understand how to properly manage forest and forest management based on permits from the local government, with limited human resources (HR), and the desire to benefit from the sale of timber to support the family, so that they were easily affected by mischievous timber collectors who utilize the weak economic factors of the community around the forest area as a way to obtain forest products illegally at a price far cheaper than the market price. 
One of the perpetrators of illegal logging in Roko Village, Mr. Simon Bale, revealed that those working as operator or people who carried out illegal logging did not know the proper management of timber forest products, they thought that cutting down a few trees might not damage the forest because former logged-over areas might be overgrown with trees, so that it might not damage the forest. ${ }^{5}$ Seeing from the logging activities, they did not consider the logging site since they cut down trees near rivers and ravines even some in the ravine which can damage the soil structure.

In this regard, Head of the Timber Legality Division of North Halmahera Regency, Fery Tumogob, explained that this was not in accordance with the provisions stipulated by Law Number. 18 of 2013 concerning Prevention and Eradication of Forest Destruction, article 11, article 12 and article 13 concerning provisions the act of forest destruction, article 13 paragraph 1 states that illegal felling of trees in forest land as referred to in Article 12

\footnotetext{
5 The results of the interviews with the perpetrator of illegal logging, Mr. Simon Bale on October 23, 2018
}

letter $\mathrm{c}$ is the felling of trees in forest land within a radius or distance of up to 500 (five hundred) meters from the side of dam or lake; 200 (two hundred) meters from the side of water source and the right and left side of river in swampy area; 100 (a hundred) meters from the left and right side of river; 50 (fifty) meters from the left and right side of tributary; 2 (two) times of depth of ravine from the side of ravine; and/or 130 (a hundred and thirty) times the difference between the highest tide and the lowest tide from the coastside. $^{6}$

In addition, the utilization of timber forest products carried out by the community was not accompanied by permission from forestry officials in this case the Forestry Department as explained by the Head of Timber Legality Division that the use of timber forest products for commercial purposes in limited production and production forest areas was not permitted except for fulfilling daily needs in this case was the utilization of timber forest products for firewood, but the community of North Halmahera Regency domiciled

\footnotetext{
${ }^{6}$ Ibid.
} 
around the forest area continued to cut trees in limited production and production forest areas.

In fact, the community cut down trees in limited production forest and production forest without permission from Forest Department Official, while the timber forest products were sold to employers and timber collectors who were allegedly operating illegally. Whereas Law Number. 18 of 2013 bans any logging activities in limited production forest and production forest without the permission of the authorized official. This law may allow the government to monitor every activity of utilizing forest product, especially timber forest product.

\section{Community Poverty Around The Forest Area}

Low socio-economic condition was a factor causing people living around forest areas to carry out illegal logging. This was generally the main reason for people to carry out illegal logging and occurred in communities domiciled near or in forest areas. Due to economic needs, the community had to work as illegal loggers to support their lives.
Urgent economic needs affected the community living in the surrounding forest area to practice illegal logging. As stated by Camat (Sub-Dictrict Head) of West Tobelo, Marjius Tjuluku, that the Head of Wangongira village, West Tobelo Sub-district was also a former timber operator (a woodcutter), the main factor to practice illegal logging was because most people in Wangongira Village were below the poverty line that was further aggravated by the increasing need for daily living costs and the high cost of education to send their children to school, while most people in Wangongira Village depended on agricultural and plantation products.

In addition, the income obtained by the community was uncertain because the agricultural and plantation products were affected by weather factors which might worsen and resulted in failure to harvest agricultural and plantation products. Moreover, agricultural and plantation products can be harvested after three (3) to six (6) months. The fluctuating market price may also affect their income. These were the reasons for the community to switch profession 
to wood operator (woodcutter), who practice illegal logging to fulfill their daily needs. ${ }^{7}$

The community of Roko Village, West Galela Sub-district experienced the same problem. Based on the result of an interview with Roko Village Head, Mr. Albertinus D. Sibaduan, he explained that some people in Roko Village worked as timber operator (woodcutter) to fulfill their daily needs because agricultural and plantation products were insufficient to meet the needs of their children's school fees and the cost of daily living. On the contrary, the income obtained from illegal logging activities was quite promising, illegal loggers can earn an average of Rp.5,000,000 in timber sales in a month, this was seen as more profitable than waiting for the harvest. $^{8}$

\section{Weak Law Enforcement Against Perpetrators of Illegal Logging}

Efforts to protect forest and forest product require firmness in cracking down on any perpetrator of illegal logging, which is intended to provide a deterrent effect for the perpetrator and suppress the intention or desire of

\footnotetext{
${ }^{7}$ Ibid.

${ }^{8}$ Ibid.
}

other people who want to do the same, but weak law enforcement remain to occur, making it difficult to overcome illegal logging activities in North Halmahera Regency. This requires the firmness of law enforcement and courage of the apparatus to take action against anyone who cuts down the trees without permission. Based on the finding in the field, enforcement of perpetrators of illegal logging was only limited to guidance, this certainly can not provide a deterrent effect for perpetrators of illegal logging. The researcher found that perpetrators of illegal logging were not only from the community, but also elements of law enforcement officers, in this case TNI (Indonesia Army) and Police.

The Head of North Halmahera Forest Management Unit, Mr. Fredik Nitalessy explained that illegal logging activities were hard to handle because illegal loggers were protected by individual TNI and Police, some of whom even provided fake document for the possession of timber to be used as a ticket by the perpetrator to pass timber guard posts, so that they were not detained and the 
timber were not confiscated. ${ }^{9}$ This was the proof that there was a lack of understanding from the community and the law enforcement official about the importance of maintaining forest sustainability.

\section{Lack of Supporting Facilities and Infrastructure}

Efforts to secure forest area need to be supported by adequate facilities and infrastructure, so that the surveillance and security process can run well. However, the limitations of facilities and infrastructure have made it difficult to monitor and secure forest areas in North Halmahera Regency. The Head of North Halmahera Forest Management Unit, Mr. Fredik Nitalessy stated that he only had one (1) matic motorcycle in conducting his main duty of forest surveillance and security, while North Halmahera Regional Conservation Resort Police did not have a vehicle to patrol in forest area, even though the vehicle was highly needed considering that the route to the villages near the forest area was not accessible by public transportation.

As a result, the process of illegal timber collectors identification around the forest area has not been optimal. Illegal loggers used offroad vehicles such as jeeps (hardtop) to to transport timber from illegal logging site located around four (4) to eight (8) kilometers from community village, so that patrol activities carried out by Forestry Police in monitoring and securing forest areas were ineffective, thereby increasing the intensity of illegal logging in these forest areas.

Obstacles Faced by Forestry Police in the North Halmahera Regional Conservation Resort in Preventing Illegal Logging

As a Forestry Police officer, it is essential to prevent illegal logging activities in North Halmahera Regency, this is certainly inseparable from the obstacles experienced by the Forestry Police of the North Halmahera Regional Conservation Resort. The obstacles included human resource factors, and infrastructure and facilities owned by each party in carrying out forest surveillance and security, so that the implementation of forest surveillance and security did not run well. The obstacles experienced by the Forestry Police of North Halmahera Conservation Resort are:

\footnotetext{
${ }^{9}$ Ibid.
} 
Lack of Legal Socialization to The Community Related to Ilegal Logging

In carrying out surveillance duty, the Forestry Police of the North Halmahera Regional Conservation Resort can provide socialization through mass media such as electronic media or print media, banner, or pamphlet containing invitations to participate in protected forest protection efforts. and the dangers of illegal logging, as an effort to increase public awareness and concern for the importance of sustainable protection and management of forest areas.

Based on the finding of this study, the Forestry Police of the North Halmahera Regional Conservation Resort did not make these efforts due to the limited number of personnels and funds. In fact, these efforts can be carried out by coordinating with the Forestry Department in order to conduct a socialization to the community around the forest area, so that the community will be aware of the importance of forest management and protection.

This can be carried out as a preventive effort to reduce the intention to practice illegal logging. However, this effort was not carried out due to the lack of funds owned by the North Halmahera Forestry Department. As stated by the Head of the Timber Legality Division of North Halmahera Forestry Department, the lack of funds owned by the Forestry Department hampered the socialization program to the community around the forest area.

Legal socialization to the community is essential because it can increase public awareness, especially those around the forest area where some people do not understand the proper forest management, so that the legal socialization is needed to make the people aware of the importance of forest area protection and maintenance, so that people do not arbitrarily use the forest and forest products.

Forestry Police Did Not Carry Out Routine, Sudden, Periodic or Joint Patrol in Forest Area

In carrying out its surveillance duty, the Forestry Police of North Halmahera Regional Conservation Resort shall patrol the forest area to capture illegal loggers found to practice illegal logging activities either by land or waterway, but until 
now there has not been any concrete measure taken by the Forestry Police and related agencies to conduct patrols in and around the forest area.

As stated by the Head of the North Halmahera Regional Conservation Resort, the measure taken by the Forestry Police in carrying out supervision and protection of the forest were only waiting for information from the community regarding the alleged occurrence of a forest crime. After the community reported the occurrence of a forest crime, the Forest Policy might go to the site to investigate the information. The police have not patrolled into the forest area because there was only one (1) Forestry Police, so that it was hard to conduct patrol. In addition, the absence of facilities and infrastructure in this case the vehicle and weapons was one of the factors to not implement patrol.

In fact, one of the functions of the Forestry Police in the implementation of forest surveillance and security is by conducting patrols into forest areas as a preventive effort to close opportunities for perpetrators of illegal logging. This can be overcome if the Forestry Police is able to coordinate with the North Halmahera Resort Police, so that patrol can be carried out. However, the coordination was not carried out on the grounds that the police did not seem to give a positive response so that the patrol could not be carried out. The Head of North Halmahera Regional Conservation Resort stated that the coordination with the North Halmahera Resort Police was not carried out because the Police did not respond to any Incident Report (LK) of suspected forestry crime submitted by Forestry Police, so that he did not coordinate with the Resort Police in the terms of carrying out patrol into the forest area .

\section{Loss of Coordination with Institution/Agency Associated with Operation for Forest Protection and Security}

As a functional officer, the Forestry Police has a main duty in conducting surveillance and monitoring in preventing illegal logging practices according to his duties and functions. In forest surveillance and security, the Forestry Police can take preventive and preventive measures to reduce intention and close opportunities of perpetrators of illegal logging, these 
efforts can be carried out in coordination with the Forestry Department, North Halmahera Resort Police and the TNI to monitor and protect forest areas that can be implemented either by carrying out legal socialization to the community, especially those around the forest area, carrying out patrols into the forest area and implementing strict measures against the perpetrators of illegal logging.

But in fact, the coordination that supposed to be a solution for measures to protect and secure the forest area was not implemented. This was caused by apathy from each agency that did want to coordinate with another agency. Whereas in an effort to prevent and eradicate forest destruction caused by illegal logging activities, collaboration between agencies was needed to reduce the level of forest destruction caused by the illegal logging activities. In accordance with Law Number. 18 of 2013 concerning the Prevention and Eradication of Forest Destruction that in the implementation of forest management and protection, the government creates a policy in the form of cross-sector coordination to prevent and suppress illegal logging activities that occur in forest areas. However, the coordination was not properly implemented.

As stated by the Head of the North Halmahera Regional Conservation Resort, the ego of each agency hampers the handling of illegal logging as occurred in 2014, when the Forestry Police submitted an Incident Report (LK) on suspicion of illegal timber found in one of the timber collectors and furniture in EfiEfi Village, South Tobelo Subdistrict to Polres Investigator, yet it has not been followed up by Polres Investigator in resolving the issue.

Whereas in accordance with their duties, investigators must conduct an investigation of the accuracy of reports received, conduct searches and seizure of evidence of criminal acts involving forests, forest area, and forest product in accordance with applicable laws and regulations, arrest and detain in coordination and supervision of Investigator of The National Police of the Republic of Indonesia in accordance with the Criminal Procedure Code, investigate suspect and witnesses, make and sign Police Investigation Report (BAP) 
and stop the investigation if there is insufficient evidence of illegal logging. The investigator shall immediately submit or transfer documents to the public prosecutor along with the suspect and material evidence after the investigation is complete.

Then, the public prosecutor will immediately return the case file to the National Police investigator along with instructions to complete, if the file is incomplete, the result of the investigation is returned, and the investigator shall immediately carry out additional investigation with instruction from the public prosecutor. The investigation is deemed completed within 14 days, and the public prosecutor shall not return the results of the investigation.

However, the procedure was not carried out by North Halmahera Resort Police investigator, even though forest crime was a special crime that required the investigator to immediately complete the investigation process considering that the evidence obtained in the form of timber forest product was easily damaged or decayed product or required high storage cost, so that the investigation shall be carried out as soon as possible. This was the reason for Forestry police to consider that the North Halmahera Regional Conservation Resort Police did not care about the activities of illegal loggers. As a result, Forestry Police did not coordinate with Resort Police in terms of forest surveillance and security activities.

In addition, the relevant agency in this case the North Halmahera Forest Department seemed to ignore the illegal logging crimes in North Halmahera Regency, this can be seen from the lack of seriousness of the Forest Department in preventing and handling the practice of illegal logging, where it could have been carried out by implementing a Presidential Decree Number 21 of 1995 concerning Sales, Ownership and Use of Chain Saws.

The presidential decree requires that any chain saw ownership has to be registered to the Forest Department officer to identify machine number and the identity of the chain saw owner, so that the government can easily identify and control the activities of people who have chain saws, thus facilitating the government 
in conducting surveillance and protection of forest areas.

In fact, the Presidential Decree has not been implemented by the government in this case the Forest Department, so that people were free to obtain tools often used to conduct illegal logging activities. As stated by one of the residents of Wangongira Village, Mr. Yoram Tasa, the Forest Department officer has never recorded a chain saw owned by the community so that the community can freely use this tool to fulfill their daily needs, so that illegal logging activities becomes increasingly prevalent. These conditions have caused the prevention and handling of illegal logging activities to be hampered.

In accordance with the laws and regulations in which Law Number. 18 of 2013 Article 28 clearly bans any official from ignoring task deliberately in preventing and eradicating forest destruction. Moreover, this is reinforced by criminal sanction implied in Article 104 of the Law on the Prevention and Eradication of Forest Destruction that any official who knowingly lets illegal logging, but does not take an action shall be sentenced to a maximum of 15 (fifteen) years in jail. Then, it requires cross-sector coordination to overcome the obstacles faced by each agency, but the coordination did not run well.

Efforts to prevent illegal logging carried out by the Forestry Police in the scope of the North Halmahera Regional Conservation Resort have not been optimal, this was due to the obstacles mentioned above so that the Forestry Police only waited for reports to be submitted by the community and then following it up. Furthermore, the Forestry Police did not conduct patrol to prevent illegal logging in North Halmahera Regency, so that the duty did run well. Next, cross-sector coordination as an effort to maximize surveillance and handling illegal logging did not run well, so that illegal logging activities in North Halmahera Regency were increasingly damaging the North Halmahera forest area which had the potential to cause a disaster for the community of North Halmahera Regency.

\section{CONCLUSION}

Illegal logging activities continue to occur in North Halmahera 
Regency, caused by the lack of awareness and desire of the surrounding forest community to prevent forest destruction activities, weak law enforcement against perpetrators who violate the Law in the forestry sector, and lack of supporting facilities and infrastructure. in carrying out forest protection activities and forest security. Various obstacles faced by the Forestry police in the scope of the North Halmahera Regional Conservation Resort were the lack of legal socialization to the community, the absence of routine, sudden, periodic or joint patrols into forest areas, and the loss of coordination with agency/institution related to operation in forest protection and security.

These conditions indicated that the Forestry Police in the scope of North Halmahera Regional Conservation Resort has not been optimal and effective in preventing illegal logging, so that it is necessary to strengthen the role of the forestry police in the future, and undertake various per-emptive measures in the form of socializing the danger of illegal logging and the importance of maintenance of forest areas as a support for life in the future.

\section{BIBLIOGRAPHY}

H.S., Salim. (2006). Dasar-Dasar Hukum Kehutanan. Jakarta: Sinar Grafika.

Hotlan Samosir (2017). Responsibility of Local Government Against Sea Pollution, Plastic Waste In Sea Waters, Sorong City. Papua Law Journal Vol. 2 Issue 1, November.

Ine, Yudhawati. (2007). Pengaruh Motivasi dan Intergritas Terhadap Kinerja Polisi Kehutanan dan Departeman Kehutanan. Jakarta: PT. Raja Grafindo Persada. Jakarta.

Marzuki, Peter Mahmud. (2007). Penelitian Hukum. Jakarta: Kencana Prenada Media Group.

Murhaini Suriansyah. (2011). Hukum Kehutanan Penegakan Hukum Terhadap Kejahatan Di Bidang Kehutanan. Yogyakarta: Laksbag Grafika.

Soekanto, Soerjono and Mamudji, Sri. (2011). Poros Pengembangan Hukum Adat. Jakarta: Rajawali Pres.

Sunarso, Siswanto. (2005). Hukum Pidana Lingkungan Hidup. Jakarta: Rineka Cipta.

Zainal, Arifin. (2010). Pemberantasan lllegal Logging dan Kementerian Kehutanan. Bandung: PT. Alumni.

http://www.bps.go.id/tab_sub/view.ph p?kat=3\&tabel $=1 \&$ daftar. accessed on April 23, 2018. 
The results of the interviews with the perpetrator of illegal logging,
Mr. Simon Bale on October 23, 2018 